\title{
Data Mining Menggunakan Algoritma Apriori dalam Rekomendasi Produk Restoran
}

\author{
Laurentinus $^{\# 1}$ \\ \#Jurusan Teknik Informatika, Fakultas Teknologi Informasi, ISB Atma Luhur \\ Jl. Jendral Sudirman, Kel. Selindung Baru, Kec. Gabek, Pangkalpinang, Prov. Bangka Belitung \\ ${ }^{1}$ Laurentinuseatmaluhur.ac.id
}

\begin{abstract}
Abstrak - Pemanfaatan teknologi Data mining kini telah banyak diterapkan di perusahaan besar di berbagai aspek. Namun sayangnya, masih banyak usaha-usaha di Indonesia yang belum memanfaatkan teknologi data mining dalam meningkatkan rencana strategis usaha kedepan, data-data yang masuk ke perusahaan hanya menjadi data history, masuk ke arsip perusahaan dan akhirnya dibiarkan tersimpan. Perusahaan dituntut memberikan layanan yang mudah dan cepat kepada customer serta menentukan strategi bisnis kedepannya, khususnya pada Restoran Bahari Bangka Belitung dalam melayani wisatawan mendapatkan fakta bahwa wisatawan sangat sulit menentukan produk yang ingin dipesan dan meminta rekomendasi kepada pelayan. Berdasarkan masalah yang dihadapi ini dapat diselesaikan dengan memanfaatkan data transaksi yang diolah dalam memberikan rekomendasi produk atau menu unggulan yang terkait untuk kepentingan pemasaran. Data mining melakukan penggalian data yang sudah tersimpan dalam jangka waktu tertentu untuk dijadikan refrensi didalam memberikan rekomendasi. Algoritma dalam penelitian ini adalah algoritma apriori berbasis website dan android dengan menggunakan metode prototype. Hasil dari penelitian ini yaitu rekomendasi apriori terhadap produk dalam bentuk aturan asosiatif atau pola transaksi customer dengan cara mengumpulkan data transaksi lalu dengan eksperimen dataset sejumlah 274 transaksi dihitung menggunakan algoritma Apriori dengan nilai support minimal 50 dan nilai confidence minimal $75 \%$. Pengujian User Acceptance Testing dari 6 variabel dengan detail 10 pertanyaan mengenai effort expectancy, social influence, performance expectancy, use behavior, supporting facilitating dan behavioral intention menghasilkan indeks rata-rata sebesar $90.4 \%$.
\end{abstract}

Kata kunci - Data mining, apriori, aturan asosiatif, rekomendasi produk, android

\section{PEndahuluan}

Pemanfaatan teknologi telah berkembang di masyarakat Indonesia dan usaha-usaha telah banyak menerakpan teknologi yang dampaknya sangat baik dalam menjalankan usaha menjadikan proses bisnis menjadi efisien dan efektif dalam melayani, namun sayangnya dibidang Data mining masih belum banyak dimanfaatkan dalam meningkatkan rencana strategis usaha kedepan, data-data yang masuk ke perusahaan hanya menjadi data history, masuk ke rekapan perusahaan dan akhirnya dibiarkan tersimpan. Data-data yang penting ini menjadi junk file jika tidak diolah. [1]

Perusahaan yang terdapat di Indonesia memasuki tahap mulai menerapkan teknologi ke dalam usaha namun belum memiliki pengetahuan bahwa data yang masuk dapat dimanfaatkan dalam menentukan strategi usaha kedepannya, seperti yang dilakukan oleh Restoran Bahari Bangka Belitung yang terdapat di Provinsi Bangka Belitung yang masuk ke sektor pariwisata dan usahausaha lainnya yang ada di Indonesia, dalam memasarkan produk/menu tanpa strategi hanya dengan pricelist dari produk. Masalah yang dihadapi oleh wisatawan yaitu belum mengetahui produk unggulan dari suatu daerah sehingga membutuhkan rekomendasi dalam mengorder, rekomendasi ini merupakan kombinasi dari 1 produk dengan produk yang lain yang saling terkait. Masalah ini tentunya berdampak terhadap kepuasan pelanggan dan berdampak terhadap pelanggan akan kembali atau tidak.

Restoran dituntut untuk pelayanan yang cepat dalam melayani customer, hal yang sama dengan customer restoran menginginkan cepat dalam memesan menu, mudah dan memilih menu yang tepat. Mudah yang diharapkan yaitu proses pemesanan yang berbasis teknologi mobile. Pihak restoran membutuhkan sistem agar dapat manajemen restoran kebutuhan customer serta perusahaan. Sistem memudahkan manajemen restoran dalam menyimpan transaksi, memberikan rekomendasi kepada customer, dan mengatur mengatur status ketersediaan menu secara realtime.

Masalah yang dihadapi ini dapat diselesaikan perusahaan dengan memanfaatkan Data mining dalam memberikan rekomendasi produk atau menu unggulan yang terkait berdasarkan data transaksi mingguan / bulanan untuk kepentingan pemasaran yaitu frequent pattern, dimana sistem memberikan informasi berupa pola yang terjadi dalam satu periode menggunakan association rule untuk mengindentifikasi hubungan antar produk. Data mining memiliki banyak algoritma, salah satu yang paling mudah diterapkan adalah algoritma apriori yang menggunakan association rule dalam menganalisis data dengan 2 parameter minimal yaitu minimum support (jumlah transaksi yang memiliki hubungan dengan produk) 
dan minimum confidence yaitu tingkat hubungan antar produk [2]-[4] penelitian ini berfokus terhadap rekomendasi produk berdasarkan tingkat hubungan yang terjadi pada data mining. Saat ini terdapat banyak penerapan algoritma apriori seperti prediksi daerah banjir [5] berdasarkan data yang dikumpulkan dapat memberikan informasi pattern terjadinya banjir sehingga dapat dilakukan pengawasan. Data mining juga dapat diimplementasi dalam komputasi masalah blackbox [6] dalam menghasilkan efisiensi dan ketahanan komputasi. Bidang Edukasi penelitian ini berupaya memberikan wawasan yang akan membantu untuk memahami kemungkinan penyebab putus sekolah [7], penelitian [8] melakukan peninjauan dengan cara yang dapat dipahami dan sangat umum yaitu bagaimana penambangan data pendidikan dan analisis pembelajaran telah diterapkan pada data Pendidikan. Improve algoritma dalam rekomendasi [9]-[11] sehingga mendapatkan performa yang lebih baik. Data mining juga dapat diterapkan berbasis cloud dalam menjalankan aplikasi [12]. Berdasarkan peneltian yang telah dilakukan didapatkan hasil bahwa data mining dapat diterapkan di berbagai sektor, ilmu, dan platform, penelitian yang dilakukan tidak hanya menguji teori algoritma apriori namun telah dicoba langsung menjadi sebuah aplikasi berbasis mobile dan web di tempat riset dalam menghasilkan rekomendasi produk.

Dengan memanfaatkan teknologi android maka proses bisnis dari usaha akan berjalan dengan efektif dan efisien, data transaksi yang masuk disimpan di database sehingga dapat dimanfaatkan oleh algoritma apriori dalam Data mining sehingga menghasilkan rekomendasi produk kepada customer yang akan ditampilkan dalam menu android

\section{Metodologi Penelitian}

Dalam Pengembangan penelitian ini penulis menggunakan model pengembangan sistem prototype. Proses dan tahapan pengembangan perangkat lunak dengan model prototype ditampilkan pada Gambar 1.

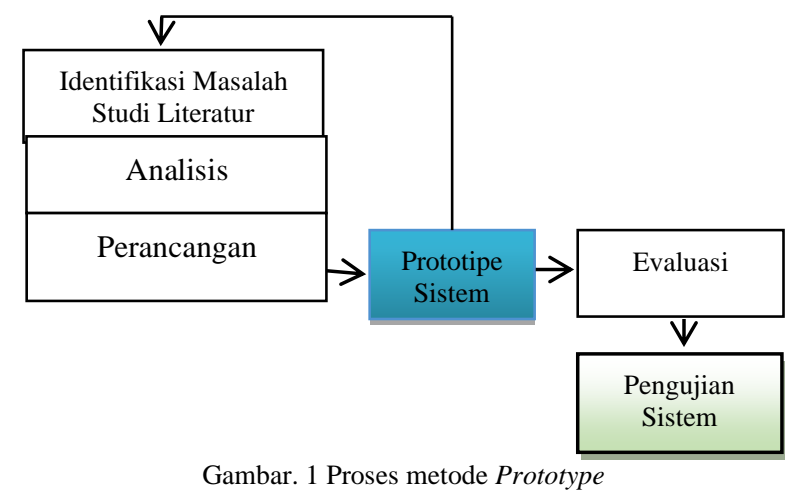

Tahapan dalam penelitian yang penulis gunakan dalam pengembangan sistem menggunakan prototype, sebagai berikut :
1) Proses Identifikasi Masalah: bertujuan untuk mengumpulkan data dari restoran bahari bangka belitung yaitu dengan cara observasi dengan mengumpulkan data sejumlah 274 transaksi.

2) Analisis: agar mengetahui kebutuhan fungsional dan non-fungsional dalam penelitian. Pembangunan sistem yang dilakukan yaitu Data mining rekomendasi produk pada Restoran Bahari Bangka Belitung berbasis android dan web dengan database MySql [13]. Analisis terhadap user yang mengakses ke sistem yaitu customer, cashier, dan manager. Analisis dilakukan terhadap proses bisnis Restoran Bahari Bangka Belitung dalam transaksi.

3) Perancangan: Setelah memperoleh data dan menganalisis seluruh kebutuhan dalam pembangunan aplikasi, proses selanjutnya dilakukan tahap desain prototype.

4) Prototipe Sistem: Proses pembangunan sistem menggunakan bahasa pemrograman php dan java dengan menerapkan algoritma apriori.

5) Pengujian Sistem: Pada proses ini, dilakukan pengujian terhadap User Acceptance dalam mengukur tingkat penerimaan perusahaan dalam menilai Data mining.

Diagram Alur Proses Data mining Apriori dapat dilihat pada Gambar 2.

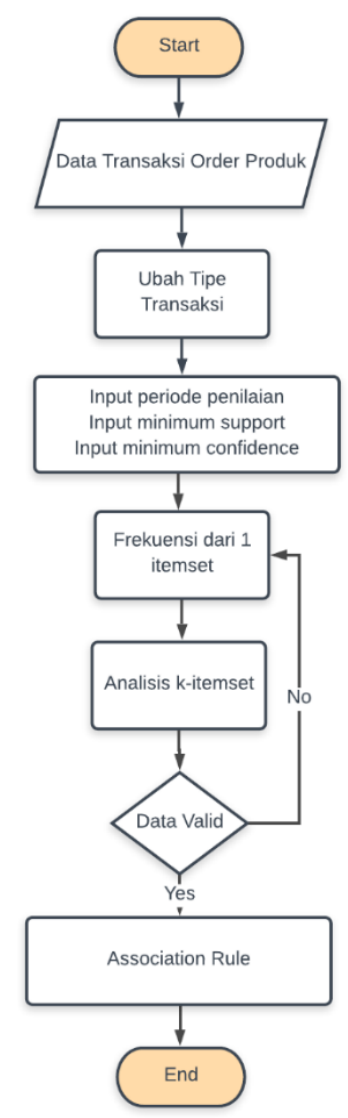

Gambar. 2 Class Diagram Data mining Restoran 


\section{A. Pengumpulan data transaksi order produk}

Pengumpulan data transaksi diperoleh dari point of sales penjualan berbasis android dengan database mysql. Struktur data yang diperoleh ditampilkan pada Tabel 1 dan Tabel 2.

TABEL I

RANCANGAN TABEL PEMESANAN

\begin{tabular}{|c|}
\hline tabel_pemesanan \\
\hline id \\
\hline id_menu \\
\hline jumlah \\
\hline user \\
\hline status \\
\hline waktu \\
\hline uniq \\
\hline
\end{tabular}

TABEL II

RANCANGAN TABEL MENU

\begin{tabular}{|c|}
\hline Tabel_menu \\
\hline id \\
\hline judul \\
\hline harga \\
\hline jenis \\
\hline jenisbb \\
\hline nama_file \\
\hline deskripsi \\
\hline
\end{tabular}

\section{B. Ubah Tipe Transaksi}

Proses mengubah tipe transaksi ini dilakukan untuk kemudahan proses data dari database dikarenakan terdapat banyak atribut yang tidak digunakan dan juga merubah pemesanan yang memiliki banyak record menu/produk dapat dijadikan menjadi 1 record dengan menu yang tersimpan didalam 1 atribut dengan nama produk. Proses ubah struktur transaksi dilakukan di sistem yang sama dan database yang sama dengan nama tabel yaitu tabel transaksi, proses ini juga mengecek data yang akan dianalisa telah sesuai, ditampilkan pada Tabel 3.

TABEL III

TABEL TRANSAKSI DATA MINING

\begin{tabular}{|c|}
\hline transaksi \\
\hline id \\
\hline transaction_date \\
\hline produk \\
\hline
\end{tabular}

C. Input Periode, minimum support, dan input minimum confidence

Proses analisis Data mining memiliki 3 parameter yaitu periode tanggal, minimum support, dan minimum confidence.

\section{Analisis Frekuensi itemset}

Proses analisis frekuensi didapatkan dengan mengolah data pada tabel transaksi berdasarkan parameter yang telah diinput yaitu periode tanggal dan minimum support untuk mencari 1-itemset dengan pola frekuensi tinggi.
Dalam menghitung nilai support item A dapat dilihat di persamaan 1, Nilai $T_{A}$ merupakan jumlah transaksi yang memiliki himpunan item A. $T_{\text {fumlah }}$ merupakan jumlah total transaksi.

$$
\text { Support }(A)=\frac{T_{A}}{T_{\text {jumiah }}}
$$

\section{E. Analisis k-itemset}

Proses analisis k-itemset dilakukan untuk mencari kombinasi antara item 1 dengan item lainnya dibagi dengan jumlah total transaksi dengan syarat minimal support sesuai dengan parameter yang diinput. Itemset yang memenuhi akan dijadikan pola frekuensi tinggi. Proses ini dilakukan berulang sehingga tidak didapatkan lagi $k$-itemset yang memenuhi kriteria perhitungan berdasarkan minimum support. Perhitunggan support ditampilkan pada persamaan 2-3.

$T_{A \cap B}$ Merupakan transaksi yang memiliki himpunan item A dan item B. $T_{A \cap B \cap C}$ merupakan transaksi yang memiliki himpunan item A, B, dan C. Perhitungan itemset akan berlanjut hingga itemset ke $\mathrm{n}$ tidak terpenuhi.

$$
\begin{aligned}
\text { Support }(A, B) & =\frac{T_{A \cap B}}{T_{\text {fumiah }}} \\
\text { Support }(A, B, C) & =\frac{T_{A \cap B \cap C}}{T_{\text {fumiah }}}
\end{aligned}
$$

\section{F. Pembentukan Association rule}

Setelah proses perhitungan nilai support maka akan dilakukan pembentukan aturan assosiatif untuk mencari nilai confidence yang sesuai dengan minimal confidence yang telah diinput. Perhitungan nilai confidence bertujuan untuk menghitung kuatnya hubungan antara beberapa item dalam association rule, association rule biasanya dinyatakan dalam $\mathrm{A} \rightarrow \mathrm{B}$, hal ini berbeda nilai confidence $\mathrm{B} \rightarrow \mathrm{A}$ dikarenakan jumlah transaksi dari $\mathrm{A}$ dan $\mathrm{B}$ berbeda dalam periode tersebut sehingga mempengaruhi hasil perhitungan confidence. Persamaan dalam perhitungan confidence dapat dilihat pada persamaan 4-5.

$$
\begin{gathered}
\text { Confidence }(A)=\frac{T_{A \cap B}}{T_{A}} \\
\text { Confidence }\left(A_{B} B\right)=\frac{T_{A \cap B \cap C}}{T_{A \cap B}}
\end{gathered}
$$

Hasil dari perhitungan aturan asosiatif yaitu nilai confidence yang melewati input nilai minimum confidence yang artinya produk tersebut memiliki tingkat hubungan yang baik dan dapat direkomendasikan. Uji lift ratio dapat dilihat pada persamaan 6-7, tujuan dari uji lift menghasilkan nilai kevalidan sebagai acuan dalam menilai apakah hubungan suatu item valid, penilaian valid tersebut dapat dilihat di hasil akhir uji lift yang bernilai lebih dari 
1,00. $B C(A, B)$ berfungsi untuk Benchmark confidence terhadap item A dan item $\mathrm{B}$, sedangkan $N_{C}$ merupakan jumlah transaksi himpunan dengan item yang menjadi consequent, dan $N$ merupakan jumlah transaksi.

$$
\begin{aligned}
\text { Uji Lift }(A, B) & =\frac{\text { Confidence }(A, B)}{B C(A, B)} \\
B C(A, B) & =\frac{N_{C}}{N}
\end{aligned}
$$

\section{HASIL DAN PEMBAHASAN}

Pembahasan pada penelitian ini mencakup 2 hal yaitu Analisa Data mining menggunakan algoritma apriori dan juga input output sistem yang menggunakan android serta website dalam mengolah data dan menghasilkan aturan asosiatif dengan uji lift dalam pengukuran kevalidan. Hasil Analisa produk akan dimasukkan kedalam sistem sehingga dapat direkomendasikan kepada pengguna. Sedangkan pengujian keefektifan sistem dalam penerapannya dilakukan dengan user acceptance test.

TABEL IV

\begin{tabular}{|c|c|c|c|}
\hline No & Item & Jumlah & Support \\
\hline 1 & Es Jeruk Peras & 168 & 61,31 \\
\hline 2 & Ayam Penyet & 82 & 29,93 \\
\hline 3 & Kentang Goreng & 75 & 27,37 \\
\hline 4 & Tongseng & 76 & 27,74 \\
\hline 5 & Pisang Goreng & 63 & 22,99 \\
\hline 6 & cumi bakar & 42 & 15,33 \\
\hline 7 & Ikan Bandeng Bakar & 61 & 22,26 \\
\hline 8 & Cah Kangkung & 16 & 5,84 \\
\hline 9 & Ayam Bakar Kalasan & 162 & 59,12 \\
\hline 10 & Ikan Lempah Kuning & 131 & 47,81 \\
\hline 11 & Ayam Cabe Ijo & 77 & 28,10 \\
\hline 12 & Jantung Pisang & 16 & 5,84 \\
\hline 13 & Jus Mangga & 25 & 9,12 \\
\hline 14 & Roti Bakar & 73 & 26,64 \\
\hline 15 & Cemilan Hits & 16 & 5,84 \\
\hline 16 & Kopi Susu Dingin dan Hangat & 28 & 10,22 \\
\hline 17 & Ikan Nila Goreng & 41 & 14,96 \\
\hline 18 & Jus alpukat & 38 & 13,87 \\
\hline 19 & Sayur Capcay & 18 & 6,57 \\
\hline 20 & Jus Apel & 39 & 14,23 \\
\hline 21 & Jus Buah Naga & 29 & 10,58 \\
\hline 22 & Jus Pisang & 26 & 9,49 \\
\hline 23 & Iga Sapi Bakar & 19 & 6,93 \\
\hline 24 & Ikan Bakar Tenggiri & 59 & 21,53 \\
\hline 25 & Ikan Saus Tiram & 45 & 16,42 \\
\hline 26 & Ayam Bakar Rawit & 76 & 27,74 \\
\hline 27 & Es Capucino & 28 & 10,22 \\
\hline 28 & Ikan Bawal Bakar & 43 & 15,69 \\
\hline 29 & Red Velvet & 12 & 4,38 \\
\hline 30 & Daging Rendang & 19 & 6,93 \\
\hline 31 & Nasi Goreng Telor & 69 & 25,18 \\
\hline 32 & Ayam Geprek & 81 & 29,56 \\
\hline 33 & Es Teh Manis & 59 & 21,53 \\
\hline 34 & Sop Iga Sapi & 18 & 6,57 \\
\hline
\end{tabular}

RANCANGAN TABEL TRANSAKSI DATA MINING

\begin{tabular}{|l|l|l|l|}
\hline No & \multicolumn{1}{|c|}{ Item } & Jumlah & Support \\
\hline 35 & Macaroni Schotel & 14 & 5,11 \\
\hline 36 & Pisang nugget & 14 & 5,11 \\
\hline 37 & Ayam Goreng Mentega & 14 & 5,11 \\
\hline 38 & charly Kentang Goreng & 3 & 1,09 \\
\hline 39 & Choco Milk & 15 & 5,47 \\
\hline
\end{tabular}

Proses pengolahan data transaksi yang pertama yaitu menganalisis frekuensi itemset A menggunakan persamaan 1, menghasilkan nilai pada Tabel 4. Dengan minimum support yaitu 50 dan minimum confidence $75 \%$ maka dilakukan filter minimum support yang memenuhi kriteria, dapat dilihat pada Tabel 5.

TABEL V

ITEMSET 1 YANG MEMENUHI

\begin{tabular}{|l|l|l|l|}
\hline No & Item & Frekuensi & Support \\
\hline 1 & Es Jeruk Peras & 168 & 61,31 \\
\hline 2 & Ayam Penyet & 82 & 29,93 \\
\hline 3 & Kentang Goreng & 75 & 27,37 \\
\hline 4 & Tongseng & 76 & 27,74 \\
\hline 5 & Pisang Goreng & 63 & 22,99 \\
\hline 6 & Ikan Bandeng Bakar & 61 & 22,26 \\
\hline 7 & Ayam Bakar Kalasan & 162 & 59,12 \\
\hline 8 & Ikan Lempah Kuning & 131 & 47,81 \\
\hline 9 & Ayam Cabe Ijo & 77 & 28,10 \\
\hline 10 & Roti Bakar & 73 & 26,64 \\
\hline 11 & Ikan Bakar Tenggiri & 59 & 21,53 \\
\hline 12 & Ayam Bakar Rawit & 76 & 27,74 \\
\hline 13 & Nasi Goreng Telor & 69 & 25,18 \\
\hline 14 & Ayam Geprek & 81 & 29,56 \\
\hline 15 & Es Teh Manis & 59 & 21,53 \\
\hline
\end{tabular}

Pembentukan itemset 2 dengan menggunakan persamaan 2, diperoleh 4 data yang memenuhi seperti pada Tabel 6.

TABEL VI

ITEMSET 2 YANG MEMENUHI

\begin{tabular}{|l|l|l|l|l|}
\hline No & \multicolumn{1}{|c|}{ Item 1 } & \multicolumn{1}{c|}{ Item 2 } & Jumlah & Support \\
\hline 1 & Es Jeruk Peras & $\begin{array}{l}\text { Ayam Bakar } \\
\text { Kalasan }\end{array}$ & 129 & 47,08 \\
\hline 2 & Es Jeruk Peras & $\begin{array}{l}\text { Ikan Lempah } \\
\text { Kuning }\end{array}$ & 110 & 40,15 \\
\hline 3 & $\begin{array}{l}\text { Ayam Bakar } \\
\text { Kalasan }\end{array}$ & $\begin{array}{l}\text { Ikan Lempah } \\
\text { Kuning }\end{array}$ & 126 & 45,99 \\
\hline 4 & $\begin{array}{l}\text { Ayam Bakar } \\
\text { Kalasan }\end{array}$ & $\begin{array}{l}\text { Ayam Bakar } \\
\text { Rawit }\end{array}$ & 51 & 18,61 \\
\hline
\end{tabular}

Pembentukan itemset 3 dengan menggunakan persamaan 3, diperoleh 1 data yang memenuhi seperti pada Tabel 7. Proses pembentukan itemset 3 menjadi akhir dari pembentukan itemset dikarenakan itemset 4 tidak terpenuhi.

TABEL VII

ITEMSET 3 YANG MEMENUHI

\begin{tabular}{|c|c|l|l|l|l|}
\hline No & Item 1 & Item 2 & Item 3 & Jumlah & Support \\
\hline \multirow{2}{*}{1} & $\begin{array}{l}\text { Es Jeruk } \\
\text { Peras }\end{array}$ & $\begin{array}{l}\text { Ayam } \\
\text { Bakar } \\
\text { Kalasan }\end{array}$ & $\begin{array}{l}\text { Ikan } \\
\text { Lempah } \\
\text { Kuning }\end{array}$ & 108 & 39,42 \\
\hline
\end{tabular}


Perhitungan nilai confidence dari itemset 2 (lihat Tabel 8) diperoleh 4 aturan yang memenuhi yaitu diatas nilai confidence diatas $75 \%$, hal ini dilakukan dalam memudahkan memberikan rekomendasi produk yaitu rekomendasi item yang kepastiannya tinggi.

TABEL VIII

CONFIDENCE DARI ITEMSET 2

\begin{tabular}{|c|l|c|c|c|c|}
\hline No & \multicolumn{1}{|c|}{ X => Y } & $\begin{array}{c}\text { Support } \\
\text { X U Y }\end{array}$ & $\begin{array}{c}\text { Support } \\
\text { X }\end{array}$ & Conf. & Ket \\
\hline 1 & $\begin{array}{l}\text { Es Jeruk Peras } \\
\text { => Ayam } \\
\text { Bakar Kalasan }\end{array}$ & 47,08 & 61,31 & 76,79 & Memenuhi \\
\hline 2 & $\begin{array}{l}\text { Ayam Bakar } \\
\text { Kalasan => Es } \\
\text { Jeruk Peras }\end{array}$ & 47,08 & 59,12 & 79,63 & Memenuhi \\
\hline 3 & $\begin{array}{l}\text { Es Jeruk Peras } \\
\text { => Ikan } \\
\text { Lempah } \\
\text { Kuning }\end{array}$ & 40,15 & 61,31 & 65,48 & $\begin{array}{l}\text { Tidak } \\
\text { Memenuhi }\end{array}$ \\
\hline 4 & $\begin{array}{l}\text { Ikan Lempah } \\
\text { Kuning => Es } \\
\text { Jeruk Peras }\end{array}$ & 40,15 & 47,81 & 83,97 & Memenuhi \\
\hline 5 & $\begin{array}{l}\text { Ayam Bakar } \\
\text { Kalasan => } \\
\text { Ikan Lempah } \\
\text { Kuning }\end{array}$ & 45,99 & 59,12 & 77,78 & Memenuhi \\
\hline 6 & $\begin{array}{l}\text { Ikan Lempah } \\
\text { Kuning => } \\
\text { Ayam Bakar } \\
\text { Kalasan }\end{array}$ & 45,99 & 47,81 & 96,18 & Memenuhi \\
\hline 7 & $\begin{array}{l}\text { Ayam Bakar } \\
\text { Kalasan => } \\
\text { Ayam Bakar } \\
\text { Rawit }\end{array}$ & $\begin{array}{l}\text { Ayam Bakar } \\
\text { Rawit => } \\
\text { Ayam Bakar } \\
\text { Kalasan }\end{array}$ & 18,61 & 59,12 & 31,48 \\
\hline
\end{tabular}

Perhitungan nilai confidence dari itemset 3 (lihat Tabel 9) diperoleh 4 aturan yang memenuhi yaitu diatas nilai confidence diatas $75 \%$.

TABEL IX

CONFIDENCE DARI ITEMSET 3

\begin{tabular}{|c|c|c|c|c|c|}
\hline \multirow{2}{*}{ No } & \multirow{2}{*}{$\mathbf{X}=>\mathbf{Y}$} & \multicolumn{2}{|c|}{ Supporisuppor } & \multirow{2}{*}{ Conf. } & \multirow{2}{*}{ Ket } \\
\hline & & $\mathbf{X ~ U ~ Y ~}$ & $\mathbf{X}$ & & \\
\hline 1 & $\begin{array}{l}\text { Es Jeruk Peras } \\
\text { Ayam Bakar } \\
\text { Kalasan => Ikan } \\
\text { Lempah Kuning }\end{array}$ & 39,42 & 47,08 & 83,72 & Memenuhi \\
\hline 2 & $\begin{array}{l}\text { Ayam Bakar } \\
\text { Kalasan, Ikan } \\
\text { Lempah Kuning => } \\
\text { Es Jeruk Peras }\end{array}$ & 39,42 & 45,99 & 85,71 & Memenuhi \\
\hline 3 & $\begin{array}{l}\text { Ikan Lempah } \\
\text { Kuning, Es Jeruk } \\
\text { Peras => Ayam } \\
\text { Bakar Kalasan }\end{array}$ & 39,42 & 40,15 & 98,18 & Memenuhi \\
\hline 4 & $\begin{array}{l}\text { Es Jeruk Peras => } \\
\text { Ikan Lempah }\end{array}$ & 39,42 & 61,31 & 64,29 & $\begin{array}{l}\text { Tidak } \\
\text { Memenuhi }\end{array}$ \\
\hline
\end{tabular}

\begin{tabular}{|c|l|c|c|c|c|}
\hline No & \multicolumn{1}{|c|}{ X => Y } & \multicolumn{2}{|c|}{ SupporiSuppor } \\
X U Y & X & Conf. & Ket \\
\hline & $\begin{array}{l}\text { Kuning, Ayam } \\
\text { Bakar Kalasan }\end{array}$ & & & & \\
\hline 5 & $\begin{array}{l}\text { Ayam Bakar } \\
\text { Kalasan => Es Jeruk } \\
\text { Peras, Ikan Lempah } \\
\text { Kuning }\end{array}$ & 39,42 & 59,12 & 66,67 & $\begin{array}{l}\text { Tidak } \\
\text { Memenuhi }\end{array}$ \\
\hline 6 & $\begin{array}{l}\text { Ikan Lempah } \\
\text { Kuning => Ayam } \\
\text { Bakar Kalasan, Es } \\
\text { Jeruk Peras }\end{array}$ & 39,42 & 47,81 & 82,44 & Memenuhi \\
\hline
\end{tabular}

Hasil dari perhitungan nilai confidence dari itemset 2 dan itemset 3 menhasilkan total 9 data yang memenuhi minimum support yaitu 50 dan minimum confidence yaitu $75 \%$, pembentukan aturan asosiatif dapat dilihat pada Tabel 10-11.

TABEL $X$

PEMBENTUKAN ATURAN ASOSIATIF

\begin{tabular}{|c|c|c|c|}
\hline No & $\mathbf{X}=>\mathbf{Y}$ & Confidence & $\begin{array}{l}\text { Nilai } \\
\text { Uji lift }\end{array}$ \\
\hline 1 & $\begin{array}{l}\text { Es Jeruk Peras , Ayam Bakar } \\
\text { Kalasan => Ikan Lempah Kuning }\end{array}$ & 83,72 & 1,75 \\
\hline 2 & $\begin{array}{l}\text { Ayam Bakar Kalasan, Ikan } \\
\text { Lempah Kuning => Es Jeruk Peras }\end{array}$ & 85,71 & 1,40 \\
\hline 3 & $\begin{array}{l}\text { Ikan Lempah Kuning , Es Jeruk } \\
\text { Peras => Ayam Bakar Kalasan }\end{array}$ & 98,18 & 1,66 \\
\hline 4 & $\begin{array}{l}\text { Ikan Lempah Kuning => Ayam } \\
\text { Bakar Kalasan, Es Jeruk Peras }\end{array}$ & 82,44 & 1,75 \\
\hline 5 & $\begin{array}{l}\text { Es Jeruk Peras => Ayam Bakar } \\
\text { Kalasan }\end{array}$ & 76,79 & 1,30 \\
\hline 6 & $\begin{array}{l}\text { Ayam Bakar Kalasan => Es Jeruk } \\
\text { Peras }\end{array}$ & 79,63 & 1,30 \\
\hline 7 & $\begin{array}{l}\text { Ikan Lempah Kuning => Es Jeruk } \\
\text { Peras }\end{array}$ & 83,97 & 1,37 \\
\hline 8 & $\begin{array}{l}\text { Ayam Bakar Kalasan => Ikan } \\
\text { Lempah Kuning }\end{array}$ & 77,78 & 1,63 \\
\hline 9 & $\begin{array}{l}\text { Ikan Lempah Kuning => Ayam } \\
\text { Bakar Kalasan }\end{array}$ & 96,18 & 1,63 \\
\hline
\end{tabular}

TABEL XI

HASIL ANALISA

\begin{tabular}{|l|l|}
\hline No & \multicolumn{1}{|c|}{ Hasil Analisa } \\
\hline 1 & $\begin{array}{l}\text { Jika } \text { customer memesan Es Jeruk Peras, Ayam Bakar } \\
\text { Kalasan, maka customer juga akan memesan Ikan } \\
\text { Lempah Kuning }\end{array}$ \\
\hline 2 & $\begin{array}{l}\text { Jika } \text { customer memesan Ayam Bakar Kalasan, Ikan } \\
\text { Lempah Kuning, maka customer juga akan memesan } \\
\text { Es Jeruk Peras }\end{array}$ \\
\hline 3 & $\begin{array}{l}\text { Jika } \text { customer memesan Ikan Lempah Kuning, Es } \\
\text { Jeruk Peras, maka customer juga akan memesan } \\
\text { Ayam Bakar Kalasan }\end{array}$ \\
\hline 4 & $\begin{array}{l}\text { Jika customer memesan Ikan Lempah Kuning, maka } \\
\text { customer juga akan memesan Ayam Bakar Kalasan , } \\
\text { Es Jeruk Peras }\end{array}$ \\
\hline 5 & $\begin{array}{l}\text { Jika } \text { customer memesan Es Jeruk Peras, maka } \\
\text { customer juga akan memesan Ayam Bakar Kalasan }\end{array}$ \\
\hline 6 & $\begin{array}{l}\text { Jika } \text { customer memesan Ayam Bakar Kalasan, maka } \\
\text { customer juga akan memesan Es Jeruk Peras }\end{array}$ \\
\hline 7 & $\begin{array}{l}\text { Jika } \text { customer memesan Ikan Lempah Kuning, maka } \\
\text { customer juga akan memesan Es Jeruk Peras }\end{array}$ \\
\hline
\end{tabular}




\begin{tabular}{|l|l|}
\hline 8 & $\begin{array}{l}\text { Jika customer memesan Ayam Bakar Kalasan, maka } \\
\text { customer juga akan memesan Ikan Lempah Kuning }\end{array}$ \\
\hline 9 & $\begin{array}{l}\text { Jika customer memesan Ikan Lempah Kuning, maka } \\
\text { customer juga akan memesan Ayam Bakar Kalasan }\end{array}$ \\
\hline
\end{tabular}

\section{A. Eksperimen Sistem}

Pengujian sistem berdasarkan eksperimen Data mining algoritma apriori dibagi menjadi 2 bagian yaitu data transaksi yang berbasis android yang menjadi input serta output kepada Data mining sehingga dapat memberikan rekomendasi produk kepada pelanggan, dan yang kedua adalah proses perhitungan apriori yang berbasis website [14], [15]. Tampilan layar aplikasi Data mining berbasis website dapat dilihat pada Gambar 3.

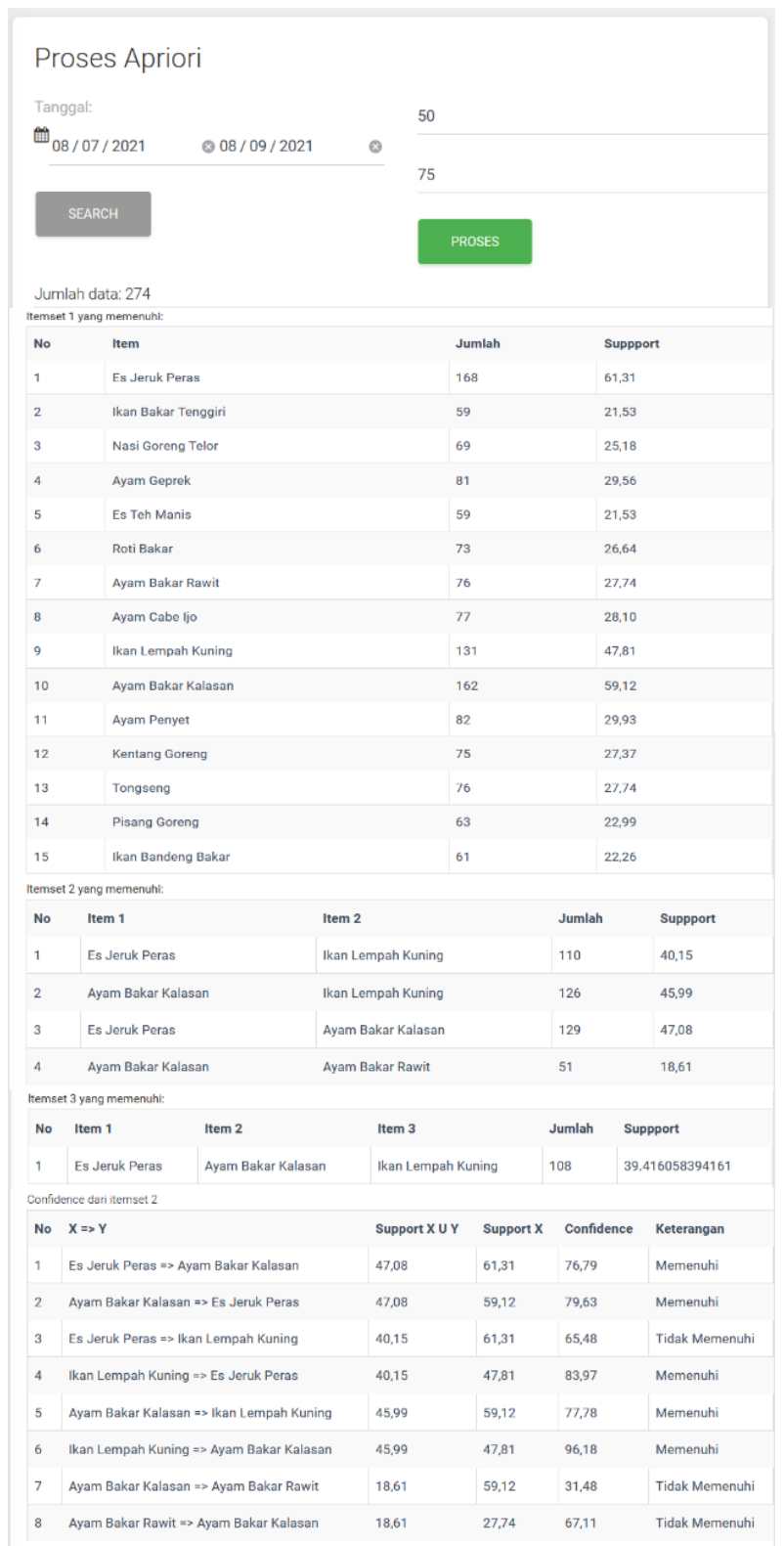

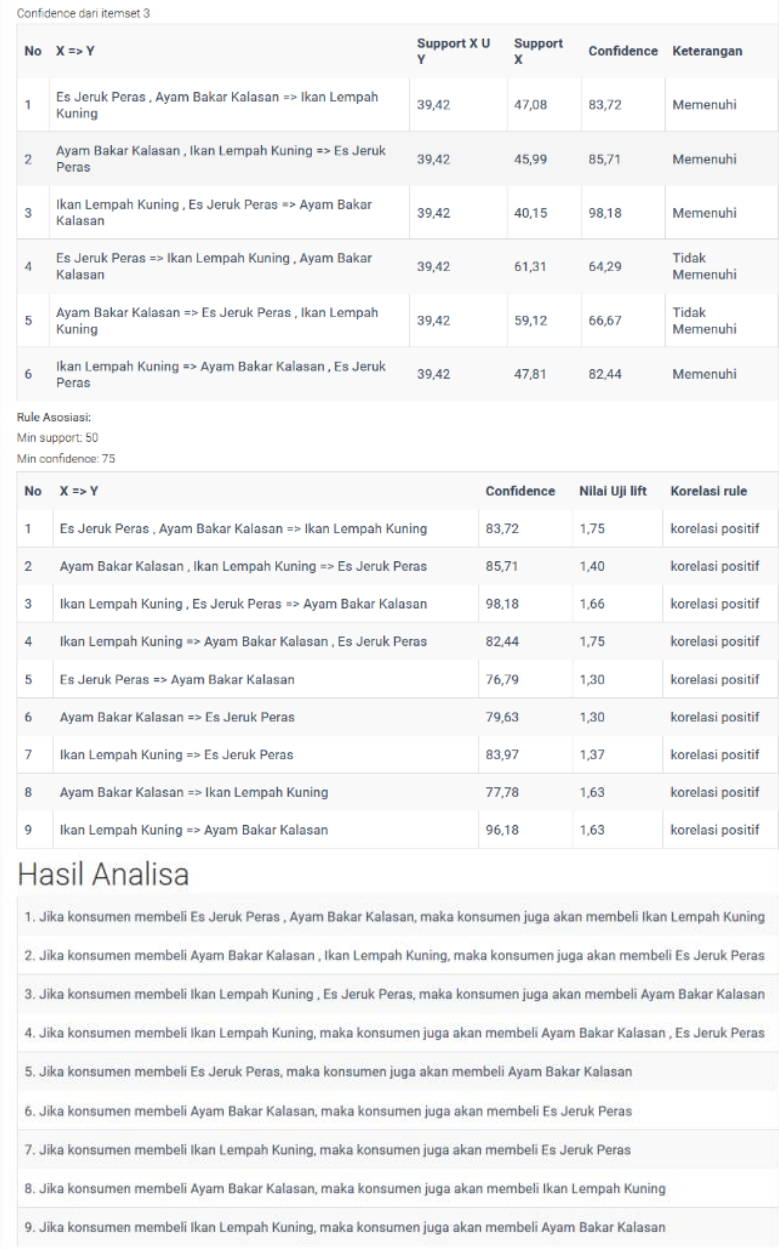

Gambar 3 Tampilan perhitungan Data mining Apriori

Proses perhitungan mengisi tanggal, minimum support yaitu 50 dan minimum confidence $75 \%$ memberikan hasil yang sama dengan Tabel 4-11. Data yang telah diproses akan mendapatkan hasil rule asosiatif yang akan dimanfaatkan dalam menentukan strategi bisnis dengan memberikan paket yang lebih diminati customer. Menu/produk rekomendasi akan tampil ketika pelanggan meminta rekomendasi menu pada aplikasi android baik dalam bentuk paket maupun berdasarkan item/produk.
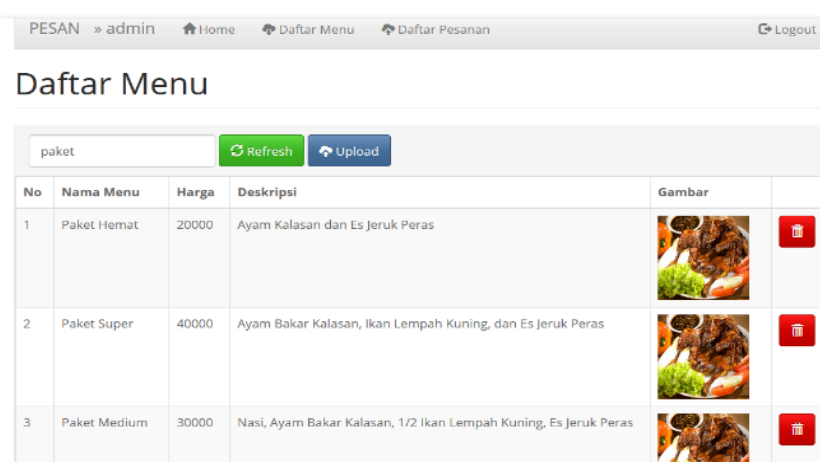

Gambar 4 Membuat paket berdasarkan itemset 2 dan itemset 3 
Berdasarkan hasil Data mining apriori maka memberikan rekomendasi item-item kepada pemilik dalam menyusun paket menu, sehingga pelanggan yang memasukkan ayam kalasan akan mendapatkan rekomendasi 3 paket tersebut (lihat pada Gambar 4).
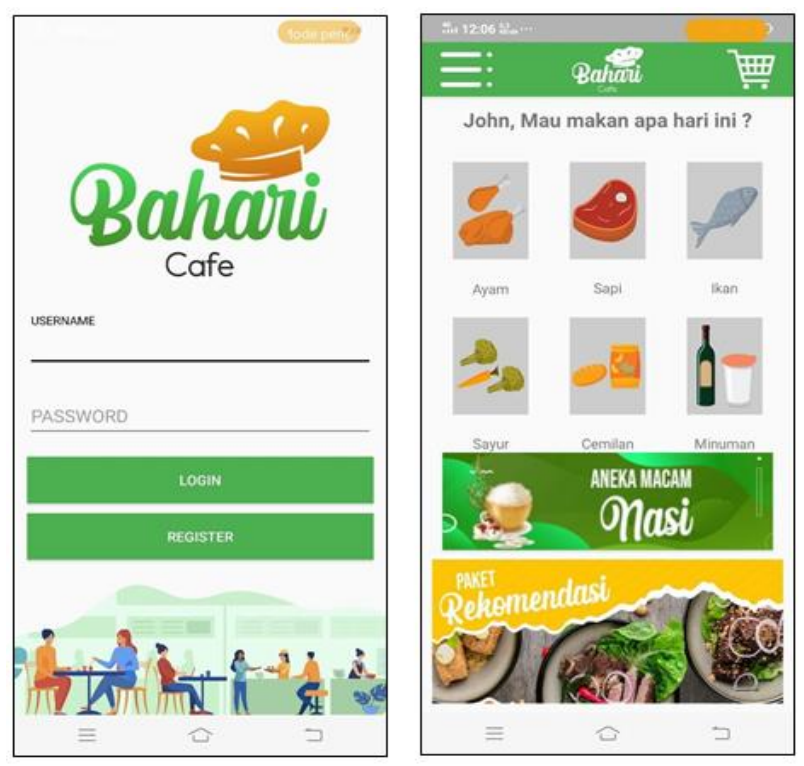

Gambar 5 Tampilan menu utama

Aplikasi android dapat dilihat pada Gambar 5, dimana pelayan akan melakukan login untuk membuka halaman utama, dan memasukkan data-data pemesanan pelanggan seperti pada Gambar 6. Data transaksi yang diinput akan dianalisa oleh apriori.

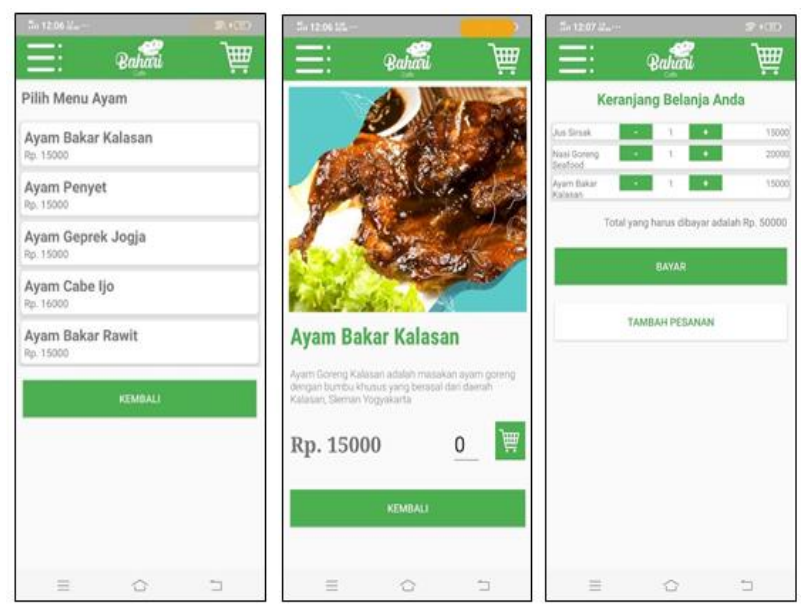

Gambar 6 Tampilan menu pemesanan

Produk yang direkomendasi oleh algoritma apriori akan ditampilkan Ketika pelanggan klik icon rekomendasi di menu cart yang akan menampilkan paket-paket yang berhubungan dengan produk yang dipilih pelanggan, minimum support 50 dan minimum confidence $75 \%$. jika terdapat menu/produk yang memenuhi serta bernilai korelatif positif akan muncul menu rekomendasi, seperti pada Gambar 7. Pelanggan akan dimudahkan dalam memilih suatu produk yang dipaketkan, yang akhirnya akan berdampak terhadap penjualan, efektifitas promosi, dan penerapan sistem yang diterima oleh pengguna karena efektif dan efisien.

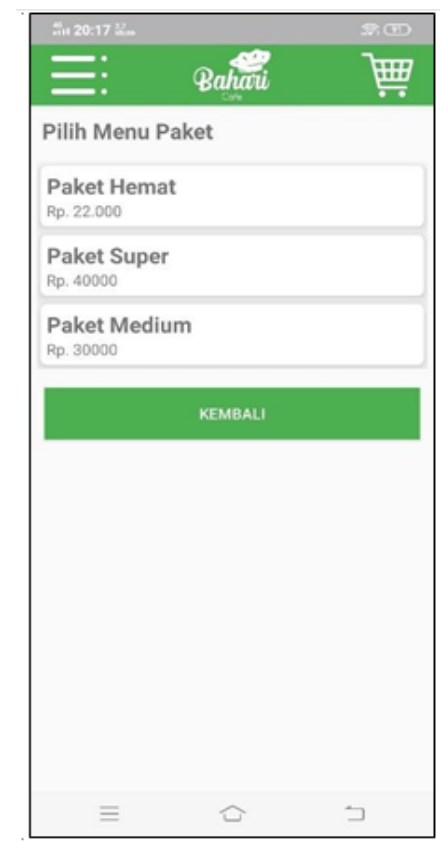

Gambar 7 Tampilan Rekomendasi Apriori

\section{B. Pengujian UAT (User Acceptance Testing)}

Pengujian yang dilakukan dalam riset ini menggunakan kuisioner dengan perhitungan menggunakan skala likert (lihat Tabel 12). Pengujian dilakukan terhadap pimpinan dan pengurus Restoran Bahari.

TABEL XII

PILIHAN JAWABAN SERTA BOBOT UAT

\begin{tabular}{|l|l|l|}
\hline Jawaban & \multicolumn{1}{|c|}{ Penjelasan } & Bobot \\
\hline $\mathrm{A}$ & $\begin{array}{l}\text { Sangat : Baik/Sesuai/Mudah } \\
\text { /Sering }\end{array}$ & 5 \\
\hline $\mathrm{B}$ & Baik/Sesuai/ Mudah /Sering & 4 \\
\hline $\mathrm{C}$ & C. Rata-rata/Biasa & 3 \\
\hline $\mathrm{D}$ & $\begin{array}{l}\text { Cukup : Baik/Sesuai/Sulit } \\
\text { /Kadang }\end{array}$ & 2 \\
\hline $\mathrm{E}$ & Sangat : Jelek/TidakSesuai /Jarang & 1 \\
\hline
\end{tabular}

Kuisioner memuat pertanyaan-pertanyaan dalam pengukuran user acceptance [16], variable ditunjukkan pada tabel 13 .

TABEL XIII

PERTANYAAN PADA KUESIONER

\begin{tabular}{|l|l|l|}
\hline Q1 & \multicolumn{1}{|c|}{ Pertanyaan } & \multicolumn{1}{|c|}{ Variabel } \\
\hline $\begin{array}{l}\text { Apakah Kinerja data mining } \\
\text { memberikan peningkatan } \\
\text { penjualan? }\end{array}$ & $\begin{array}{l}\text { Performance } \\
\text { Expectancy }\end{array}$ \\
\hline Q2 & $\begin{array}{l}\text { Apakah data mining mempermudah } \\
\text { pelayanan? }\end{array}$ & $\begin{array}{l}\text { Performance } \\
\text { Expectancy }\end{array}$ \\
\hline
\end{tabular}




\begin{tabular}{|c|c|c|}
\hline & Pertanyaan & Variabel \\
\hline Q3 & $\begin{array}{l}\text { Apakah data mining meningkatkan } \\
\text { kualitas usaha? }\end{array}$ & $\begin{array}{l}\text { Performance } \\
\text { Expectancy }\end{array}$ \\
\hline Q4 & $\begin{array}{l}\text { Apakah data mining telah sesuai } \\
\text { dengan apriori ? }\end{array}$ & $\begin{array}{l}\text { Performance } \\
\text { Expectancy }\end{array}$ \\
\hline Q4 & $\begin{array}{l}\text { Apakah data mining dapat } \\
\text { meningkatkan efektifitas serta } \\
\text { efisiensi dalam rekomendasi? }\end{array}$ & $\begin{array}{l}\text { Effort } \\
\text { Expectancy }\end{array}$ \\
\hline Q5 & $\begin{array}{l}\text { Apakah aplikasi Data mining } \\
\text { mudah digunakan? }\end{array}$ & $\begin{array}{l}\text { Effort } \\
\text { Expectancy }\end{array}$ \\
\hline Q6 & $\begin{array}{l}\text { Apakah nyaman dengan Interface } \\
\text { aplikasi ? }\end{array}$ & $\begin{array}{l}\text { Effort } \\
\text { Expectancy }\end{array}$ \\
\hline Q7 & $\begin{array}{l}\text { Apakah founder akan menerapkan } \\
\text { data mining kedalam usaha? }\end{array}$ & Social Influence \\
\hline Q7 & $\begin{array}{l}\text { Apakah skill pengguna cukup } \\
\text { dalam menguasai aplikasi ? }\end{array}$ & $\begin{array}{l}\text { Supporting } \\
\text { Facilitating }\end{array}$ \\
\hline Q8 & $\begin{array}{l}\text { Sisem Kompatibel dengan } \\
\text { perangkat kerja? }\end{array}$ & $\begin{array}{l}\text { Supporting } \\
\text { Facilitating }\end{array}$ \\
\hline Q9 & $\begin{array}{l}\text { Apakah data mining akan } \\
\text { digunakan dalam merekomendasi } \\
\text { menggantikan rekomendasi } \\
\text { manual? }\end{array}$ & $\begin{array}{l}\text { Behavioral } \\
\text { Intention }\end{array}$ \\
\hline $\begin{array}{l}\text { Q1 } \\
0\end{array}$ & $\begin{array}{l}\text { Seberapa intensitas menggunakan } \\
\text { sistem rekomendasi produk? }\end{array}$ & Use Behavior \\
\hline
\end{tabular}

Hasil pengujian User Acceptance terhadap 5 pemangku kepentingan pada Restoran Bahari Bangka Belitung, ditunjukkan pada Tabel 14.

TABEL XIV

HASIL PENGUJIAN

\begin{tabular}{|c|c|c|c|c|c|c|c|}
\hline & \multicolumn{5}{|c|}{ Nilai } & \multirow{2}{*}{ Jumlah } & \multirow{2}{*}{ Persentase } \\
\hline & $\mathbf{A}$ & B & $\mathbf{C}$ & D & $\mathbf{E}$ & & \\
\hline Q1 & $4 \times 5$ & $1 \times 4$ & & & & 24 & $96 \%$ \\
\hline Q2 & $3 \times 5$ & $2 \times 4$ & & & & 23 & $92 \%$ \\
\hline Q3 & $3 \times 5$ & $2 \times 4$ & & & & 23 & $92 \%$ \\
\hline $\mathrm{Q} 4$ & $4 \times 5$ & $1 \times 4$ & & & & 24 & $96 \%$ \\
\hline $\mathrm{Q} 4$ & $1 \times 5$ & $3 \times 4$ & $1 \times 3$ & & & 20 & $80 \%$ \\
\hline Q5 & $4 \times 5$ & $1 \times 4$ & & & & 24 & $96 \%$ \\
\hline Q6 & $3 \times 5$ & & $2 \times 3$ & & & 21 & $84 \%$ \\
\hline Q7 & $3 \times 5$ & $2 \times 4$ & & & & 23 & $92 \%$ \\
\hline Q7 & $4 \times 5$ & $1 \times 4$ & & & & 24 & $96 \%$ \\
\hline Q8 & & $5 \times 4$ & & & & 20 & $80 \%$ \\
\hline \multicolumn{7}{|c|}{ Rata-Rata } & $90.4 \%$ \\
\hline
\end{tabular}

Rata-rata indeks dari pengujian User Acceptance yakni $90.4 \%$, yang artinya sistem berjalan sangat baik dan mampu memberikan kinerja yang sangat baik terkait performance, supporting facilitating, effort expectancy, social influence, behavioral intention dan use behavior.

\section{KESIMPULAN}

Berdasarkan analisis dan hasil penelitian maka dapat disimpulkan sistem rekomendasi menggunakan algoritma apriori dapat diterapkan di seluruh usaha baik dagang maupun jasa dalam menentukan strategi bisnis. Penelitian ini menganalisis data transaksi dengan minimum support 50 dan minimum confidence $75 \%$ yang menghasilkan association rule / pola transaksi dari customer sehingga didapatkan nilai uji lift yang diatas 1.00 sebagai data yang valid, kemudian ditampilkan di aplikasi android sebagai rekomendasi paket produk. Data mining dengan algoritma apriori juga sangat membantu dalam memberikan strategi bisnis, dapat diterapkan dengan baik di berbagai perangkat yaitu android dan website dengan pengujian user acceptance testing didapatkan nilai kinerja yang sangat baik yaitu $90.4 \%$.

\section{REFERENSI}

[1] P. H. Simbolon, "Implementasi Data Mining Pada Sistem Persediaan Barang Menggunakan Algoritma Apriori ( Studi Kasus : Srikandi Cash Credit Elektronic dan Furniture )," J. Ris. Komput., vol. 6, no. 4, 2019.

[2] C. Adiwihardja, N. Hardi, and W. Widyastuty, "Implementasi Data Mining Penjualan Kosmetik Pada Toko Zahrani Menggunakan Algoritma Apriori," J. Speed-Sentra Penelit. Eng. dan Edukasi, vol. 11, no. 2, 2019.

[3] A. R. Riszky and M. Sadikin, "Data Mining Menggunakan Algoritma Apriori untuk Rekomendasi Produk bagi Pelanggan," $J$ Teknol. dan Sist. Komput., vol. 7, no. 3, 2019, doi: 10.14710/jtsiskom.7.3.2019.103-108.

[4] S. Saefudin and D. Fernando, "PENERAPAN DATA MINING REKOMENDASI BUKU MENGGUNAKAN ALGORITMA APRIORI," JSiI (Jurnal Sist. Informasi), vol. 7, no. 1, 2020, doi: 10.30656/jsii.v7i1.1899

[5] N. A. Harun, M. Makhtar, A. A. Aziz, Z. A. Zakaria, F. S Abdullah, and J. A. Jusoh, "The application of Apriori algorithm in predicting flood areas," Int. J. Adv. Sci. Eng. Inf. Technol., vol. 7, no. 3, pp. 763-769, 2017, doi: 10.18517/ijaseit.7.3.1463.

[6] J. Liu, H. Dong, and P. Wang, "Multi-fidelity global optimization using a data-mining strategy for computationally intensive blackbox problems," Knowledge-Based Syst., vol. 227, 2021, doi: 10.1016/j.knosys.2021.107212.

[7] M. Marufuzzaman, D. J. Gomes, A. A. A. Rupai, and L. M. Sidek, "Discovering rules for nursery students using apriori algorithm," Bull. Electr. Eng. Informatics, vol. 9, no. 1, 2020, doi: 10.11591/eei.v9i1.1665.

[8] C. Romero and S. Ventura, "Educational data mining and learning analytics: An updated survey," Wiley Interdiscip. Rev. Data Min. Knowl. Discov., vol. 10, no. 3, 2020, doi: 10.1002/widm.1355.

[9] P. K. Singh, E. Othman, R. Ahmed, A. Mahmood, H. Dhahri, and P. Choudhury, "Optimized recommendations by user profiling using apriori algorithm," Appl. Soft Comput., vol. 106, 2021, doi: 10.1016/j.asoc.2021.107272.

[10] R. Sun, "A combination of prefixed-itemset and database optimization to improve apriori algorithm on hadoop cluster," 2019, doi: 10.1109/ICMCCE48743.2019.00223.

[11] S. Yu, "A kind of improved algorithm for weighted Apriori and application to data mining," 2010, doi: 10.1109/ICCSE.2010.5593564.

[12] J. J. Fang and X. L. Li, "Research on the application of cloud computing in data mining algorithm," Agro Food Ind. Hi. Tech., vol. 28, no. 3, 2017.

[13] H. Sakai, M. Nakata, and J. Watada, "NIS-Apriori-based rule generation with three-way decisions and its application system in SQL," Inf. Sci. (Ny)., vol. 507, 2020, doi: 10.1016/j.ins.2018.09.008.

[14] M. J. Hamid Mughal, "Data mining: Web data mining techniques, tools and algorithms: An overview," Int. J. Adv. Comput. Sci. Appl., vol. 9, no. 6, 2018, doi: 10.14569/IJACSA.2018.090630.

[15] Z. Q. Wang and H. L. Li, "Research of massive web log data mining based on cloud computing," 2013, doi: 10.1109/ICCIS.2013.162.

[16] L. Laurentinus and S. Rinaldi, "Implementasi Metode Analytical Hierarchy Process dan Simple Additive Weighting untuk Pemilihan Dosen Terbaik Studi Kasus STMIK Atma Luhur," J. Teknol. Inf. dan Ilmu Komput., 2019, doi: 10.25126/jtiik.2019661636. 